\title{
Non-Prescription Drug Distribution in Italy: The Role of Large-Scale Retailers
}

\author{
Sabina Riboldazzi \\ Assistant Professor of Management, University of Milano-Bicocca, Italy \\ Doi: 10.19044/esj.2017.v13n31p7 URL:http://dx.doi.org/10.19044/esj.2017.v13n31p7
}

\begin{abstract}
In recent years, a series of regulatory actions have reformed the Italian pharmaceutical supply chain, particularly that of non-prescription drugs. The present study analyzes the distribution phase of non-prescription drugs. Specifically, it focuses on the retail market of pharmaceuticals in Italy, highlighting the different sales formats and the role played by those large-scale retailers that have been able to develop new pharmaceutical offerings in their point of sales through dynamic management of retailing mix levers in a competitive perspective.
\end{abstract}

Keywords: Non-prescription drug marketing channels; pharmaceutical supply chain; large-scale retailers

\section{Introduction}

Large-scale retailing in the grocery sector is currently characterized by a limited number of companies operating on different market areas, which are continuously developing innovative market offerings. The high competition faced by large-scale retail companies while operating on these markets has forced them to implement different development/growth strategies aimed at maintaining or strengthening their competitive positions (Robinson and Clarke-Hill, 1990; Basker et al., 2012; Riboldazzi, 2015a). In particular, common growth/development strategies implemented by largescale retail companies include the following:

- $\quad$ strengthening and improving the productivity and efficiency of existing offering, with only small changes in assortments, keeping into account the retailer reference segment market;

- upgrading the market offering, and sometimes the format, with reference to existing points of sale as well as to the opening of new points of sale in domestic or foreign markets; such upgrades can be achieved by developing and selling new goods or services related to the core offering, 
able to meet segment market demand linked to the reference market of the retailer;

- developing new product ranges unrelated to the core offering, with reference to existing points of sale as well as to the opening of new ones, to meet new domestic and foreign segment market demand.

Obviously, each development trajectory strictly depends on the specific innovation process being implemented by the company (Musso, 2010). In particular, the choice to undertake a certain development trajectory rather than another one, along with the required innovation process, strictly relies on the retailer's ability to swiftly identify and use to its advantage market opportunities deriving from changes in demand, offer, and environmental factors.

With regard to Italian market and other European markets, legislative reforms taking place in the last few years have allowed main large-scale retail companies to develop new market offerings in sectors far from their core business such as fuel, phone or finance services, and pharmaceuticals (Burt, 1991; Alexander and Pollard, 2000; Martinelli, 2012; Riboldazzi, 2010, Risso, 2010).

Through analysis of secondary data, the present study specifically aims at describing the main features of the pharmaceutical supply chain in Italy as a result of the drug retail distribution reform, while focusing on the role of large-scale retail companies in such market. In particular, this study will address the main forms of non-prescription drug retailing, with a specific focus on the retailing mix and formats developed by large-scale grocery retail companies.

In our concluding remarks, we will take into consideration the relationship between innovation and development of the pharmaceutical offerings developed by large-scale retail companies.

\section{The distribution phase in the pharmaceutical supply chain in Europe}

The pharmaceutical supply chain consists of a number of subjects, such as pharmaceutical industries, wholesalers, and retailers (e.g. retail pharmacies, drugstores, hospital pharmacies, etc.), which develop different business functions to meet drug demand.

The pharmaceutical industry is undoubtedly one of the most important industrial sector worldwide. Globally, only a few large companies play a relevant role in drug manufacturing (e.g. Novartis, Sanofi, Pfizer, Roche, and GlaxoSmithKline). Over the years, such companies have undergone many structural and operational changes such as mergers, acquisitions, horizontal, or vertical integrations, thereby achieving economies of scale. These companies are now characterized by global development, delocalization, diversification of activities, activation of 
competitive and strategic alliances-—with competitors, biotechnological industries, hospitals, research institutes, and companies supplying specific devices and equipment - and high R\&D investment to develop innovative pharmaceutical products.

Regarding production, companies involved in the global pharmaceutical industry (i.e. originator or branded companies), compete with other companies that manufacture generic drugs (e.g. Teva Pharmaceutical, Novartis, Actavis-Watson Pharmaceuticals, Mylan, and Sanofi), as well as with other minor companies in terms of product output and earnings, which include small/medium-sized enterprises specialized in the production of specific drugs, companies focused on specific indications or pharmaceutical formulations, and other companies specialized in innovation in well-defined and narrow sectors.

Among European countries, Switzerland, Germany, Italy, France, and the UK are the main manufacturers of pharmaceuticals (Efpia, 2016). With respect to the overall European pharmaceutical expenditure, the five most important markets are Germany, UK, France, Italy, and Spain. Notably, nonprescription drug expenditure amounts to $15.8 \%$ of the entire European pharmaceutical market. In this scenario, the five most important markets for non-prescription drugs are Germany, France, UK, Italy and Poland (Centro Studi Assosalute, 2016).

Once drugs have gone through the various development phases, which vary according to product type (e.g. ethical drugs, OTC, generics, etc.) and geographical area where they are produced (Riboldazzi, 2015b), they enter the distribution phase of the pharmaceutical supply chain.

The first distribution phase concerns wholesale distribution, which specifically involves a limited number of companies purchasing pharmaceuticals in bulk from manufacturers and moving them along the supply chain, thus determining the final distribution phase. Wholesale distribution develops a large number of activities such as transfer, transport, storage, information, and financing. The importance of wholesaling in the pharmaceutical supply chain is further strengthened by the fact that smallsize orders and the high-frequency delivery often required by drug retailers can significantly hamper the efficiency of direct channel distribution (i.e. manufacturer-retailer). Specifically, a proximity service such as that provided by local pharmacies, characterized by assortment specialization and small/medium-sized points of sale, requires minimum storage provisions. This would not be possible without the help of wholesalers that reduce logistics and transaction costs, secure a rapid and continuous supply of medical products, and generate value along the pharmaceutical supply chain by providing additional services (e.g. information on new products on the 
market or on drug prices, collection and disposal of expired drugs, credit on supplies, etc.) (Riboldazzi, 2012).

In the European market, wholesale distribution may include full-line or short-line wholesalers as well as other subjects like logistics operators, or groups and pharmacy cooperatives. Full-line wholesalers generally manage big stocks of drugs, which they own and operate at the regional, domestic and/or European level. Instead, short-line wholesalers operate outside the public service and deal with pharmaceutical and parapharmaceutical products of one or few manufacturers, with whom they stipulate exclusive fixed-term agreements - short-line wholesaling is not present in Italy.

Despite wholesale distribution across Europe being characterized by country-specific organizational models rather than regional ones, from a general standpoint, it can be argued that while in the countries of northern Europe there can be found an increasingly higher number of multinational distribution operators, in the countries of southern Europe there is a higher number of wholesalers, with pharmacy cooperatives playing a major role.

In a way similar to what seen for drug manufacturers, also companies involved in wholesaling have undergone profound structural and organizational changes through acquisitions, mergers, horizontal integrations among competitors, vertical integrations between pharmacies and pharmacy groups (i.e. downstream), or producers of generic or non-prescription drugs (upstream), also with regard to private label drug production. Thus, concentration and rationalization do characterize European wholesale distribution, where the three main operating groups are Celesio, Alliance Boots, and Phoenix - they account for $60 \%$ of the European wholesale market and own $35 \%$ of European pharmacy chains, besides controlling about one third of independent pharmacies grouped in cooperatives (Centro Studi Assosalute, 2016).

As far as the Italian market is concerned, wholesale distribution is characterized by the presence of two main subjects: depositaries and wholesalers. The latter ones, being owners of the goods they transfer, can work locally with a single warehouse, across regions with more than one warehouse, or be part of purchasing groups bringing together pharmacy cooperatives. In Italy, like in the rest of Europe, there have also been a number of wholesale companies undergoing mergers, acquisitions or integrations, even though with a lower frequency, with the first three groups currently accounting for about $50 \%$ of the market. In recent years, Alliance and Comifar, the two leading Italian wholesale companies, owned by Alliance Boots and Phoenix, respectively, have considerably increased their presence on the territory by purchasing domestic operators or public pharmacy shares, and joining parapharmacy chains to strengthen their competitive positions. About 33\% of wholesalers' turnover is generated by 
distribution to retailers, especially pharmacies selling non-prescription drugs and parapharmaceuticals, with the remainder being constituted by ethical drugs.

Hence, through wholesaling-57.6\% of non-prescription drugs are distributed through wholesale, while the rest is distributed directly (Centro Studi Assosalute, 2016) - , drugs can finally reach the retail distribution phase, which involves a large number of retailers (e.g. retail pharmacies, drugstores, hospital pharmacies, and dispensing doctors), which are widely spread throughout the territory, with pharmacies being the dominant channel.

Table 1. Pharmaceutical wholesale and retail distribution in selected European countries.

\begin{tabular}{|c|c|c|c|c|c|c|c|}
\hline & $\begin{array}{l}\text { Distribution } \\
\text { phase }\end{array}$ & Italy & France & $\begin{array}{c}\text { German } \\
\mathbf{y}\end{array}$ & $\begin{array}{l}\text { Netherl } \\
\text { ands }\end{array}$ & Spain & $\begin{array}{c}\text { United } \\
\text { Kingdo } \\
\text { m }\end{array}$ \\
\hline $\begin{array}{c}\text { Distributio } \\
n \text { system }\end{array}$ & & $\begin{array}{l}\text { Multi- } \\
\text { channel }\end{array}$ & $\begin{array}{l}\text { Multi- } \\
\text { channel }\end{array}$ & $\begin{array}{l}\text { Multi- } \\
\text { channel }\end{array}$ & $\begin{array}{l}\text { Multi- } \\
\text { channel }\end{array}$ & $\begin{array}{l}\text { Multi- } \\
\text { channel }\end{array}$ & $\begin{array}{l}\text { Multi- } \\
\text { channel }\end{array}$ \\
\hline $\begin{array}{c}\text { Distributio } \\
n \text { channel }\end{array}$ & \multirow{3}{*}{ Wholesale } & $\begin{array}{l}\text { Full- } \\
\text { line, } \\
\text { direct } \\
\text { sale }\end{array}$ & $\begin{array}{c}\text { Full- } \\
\text { line, } \\
\text { short- } \\
\text { line, } \\
\text { direct } \\
\text { sale } \\
\end{array}$ & $\begin{array}{c}\text { Full- } \\
\text { line, } \\
\text { short- } \\
\text { line, } \\
\text { direct } \\
\text { sale } \\
\end{array}$ & $\begin{array}{l}\text { Full-line, } \\
\text { short-line, } \\
\text { direct sale }\end{array}$ & $\begin{array}{l}\text { Full-line, } \\
\text { short-line, } \\
\text { direct sale }\end{array}$ & $\begin{array}{l}\text { Full-line, } \\
\text { short- } \\
\text { line, } \\
\text { direct } \\
\text { sale }\end{array}$ \\
\hline $\begin{array}{c}\text { Full-line } \\
\text { wholesalers }\end{array}$ & & 38 & 17 & 13 & 5 & 51 & 9 \\
\hline $\begin{array}{c}\text { of which } \\
\text { - full-line } \\
\text { domestic } \\
\text { wholesalers }\end{array}$ & & 2 & 3 & 5 & 3 & 3 & 3 \\
\hline $\begin{array}{c}\text { Non- } \\
\text { prescriptio } \\
n \\
\text { drug sale in } \\
\text { physical } \\
\text { channels } \\
\text { different } \\
\text { from } \\
\text { pharmacies }\end{array}$ & \multirow[t]{3}{*}{ Retail } & Yes & No & $\begin{array}{c}\text { Yes - } \\
\text { General } \\
\text { Sale } \\
\text { List }\end{array}$ & $\begin{array}{c}\text { Yes - } \\
\text { General } \\
\text { Sale List }\end{array}$ & No & $\begin{array}{c}\text { Yes - } \\
\text { General } \\
\text { Sale List }\end{array}$ \\
\hline Online sale & & Yes & Yes & Yes & Yes & Yes & Yes \\
\hline $\begin{array}{l}\text { Territorial } \\
\text { restrictions } \\
\text { for the } \\
\text { opening of } \\
\text { pharmacies }\end{array}$ & & Yes & Yes & No & No & Yes & No \\
\hline
\end{tabular}

Source: Data analysis of the Author based on data from Centro Studi Assosalute 2016 and AESMD - Association of the European Self-Medication Industry. 
The latter is the only physical distribution channel for many European countries, such as France, Belgium, Austria, Finland, Spain, and Greece, even though in some of these countries there may be some exceptions. For instance, in Finland it is possible to buy outside pharmacies only pharmaceuticals based on nicotine provided that the seller has a sales tax permit. Moreover, pharmaceutical assistance programs can supply OTC.

In contrast, in many other countries, all or the majority of nonprescription drugs can be sold through non-pharmacy channels. Finally, in almost all European countries it is allowed to sell drugs online.

\section{Drug retail distribution in Italy}

Since 2005, the Italian drug retail distribution system has been radically reformed thanks to a series of regulatory actions, among which we can highlight the following (Federfarma, 2015):

- $\quad$ "Bersani" Law-2006. According to this law, non-prescription drugs (i.e. OTC and SOP) are allowed to be sold in non-pharmacy channels, provided that such stores guarantee the presence of a pharmacist and make available an area dedicated exclusively to the sale of drugs (i.e. corners in large-scale retail stores). Furthermore, it allows the opening of stores able to sell non-prescription drugs just by written communication to the Ministry of Health and the Region. The "Bersani" Law has also put an end the $20 \%$ discount limit applicable to drugs, enforced in 2005 by the "Storace" Decree. Moreover, it stipulates that pharmacists can own up to four pharmacies, eliminates any incompatibility between wholesale distribution and distribution to consumers of drugs, and finally reduces to two years the deadline given to the heirs of pharmacy owners to decide whether to take ownership or surrender the pharmacies (Leg. Decree No. 201/2011, turned into Law No. 214/2011).

- $\quad$ Finance Act of 2007. It establishes that each point of sale can decide autonomously the selling price for non-prescription drugs, and eliminates any restrictions applied on pharmacy advertisement (Pharmacist Code of Conduct).

- $\quad$ Leg. Decree No. 201/2011, turned into Law No. 214/2011. It allows discounts also on Group C prescription drugs. Furthermore, in 2011 there was an increase in the range of drugs to be sold in stores in the presence of a pharmacist, while delisting some drugs previously subject to prescription.

"Cresci Italia" Decree of 2012. It reduces the ratio between pharmacies and residents from $1 / 5,000$ to $1 / 3,300$ - specifically from $1 / 4,000$ in places with more than 12,500 inhabitants and 1/5,000 in places with less than 12,500 inhabitants-allowing the opening of pharmacies, notwithstanding the quorum, in highly-frequented places such as shopping malls, railway stations, and so on. Moreover, the "Cresci Italia" Decree 
liberalizes the opening hours and allows the discount for all drugs being purchased by Italian citizens. Furthermore, it reduces to 6 months, following submission of the Statement of Succession, the term given to heirs of pharmacy owners to take ownership or surrender the pharmacy. Finally, it legalizes sales of prescription veterinary drugs and galenic compounds in general stores. The Leg. Decree known as "Concorrenza" acknowledges the possibility for limited companies to own pharmacies and start-up pharmacy chains (Federfarma, 2015).

- $\quad$ Leg. Decree of February $19^{\text {th }}, 2014$. It legalizes online sales of only non-prescription drugs, both self-medication/OTC and SOP, according to specific procedures, for all businesses holding a license for the sale of nonprescription medicinal products (Centro Studi Assosalute, 2015).

The aforementioned norms have profoundly reformed the structure, competitiveness, and operations of Italian retailers, which in recent years have been trying to shape an increasingly effective and efficient business model by improving their services, implementing cutting-edge retailing mix policies through the diversification of their market offerings, and forming partnerships and strategic alliances between companies.

In particular, due to the above-mentioned structural changes, the retail system of non-prescription drug retail distribution is now characterized by the following aspects:

- Multi-channel marketing. In the years prior to the drug retail distribution reform, the sale of drugs was only allowed in pharmacies, thereby making the pharmacy channel a true monopoly. The dominant position of pharmacies in the drug market was also due to the fact that medicinal products were regarded as atypical goods. Nonetheless, pharmacies could also sell other products related to health, which were not reserved exclusively for the pharmacy channel (e.g. homeopathic goods, nutritional supplements, herbal, dietetic and nursery products, as well as parapharmaceuticals and cosmetics). Following the reform, non-prescription drug retail distribution has shifted from mono-channel to multi-channel distribution, thereby allowing the purchase of drugs in more than one format, such as pharmacies, parapharmacies, large-scale retail stores, and online channels. 
Figure 1. Changes in non-prescription drug sales volumes in the three physical sales channels. Sell out 2007-2015.

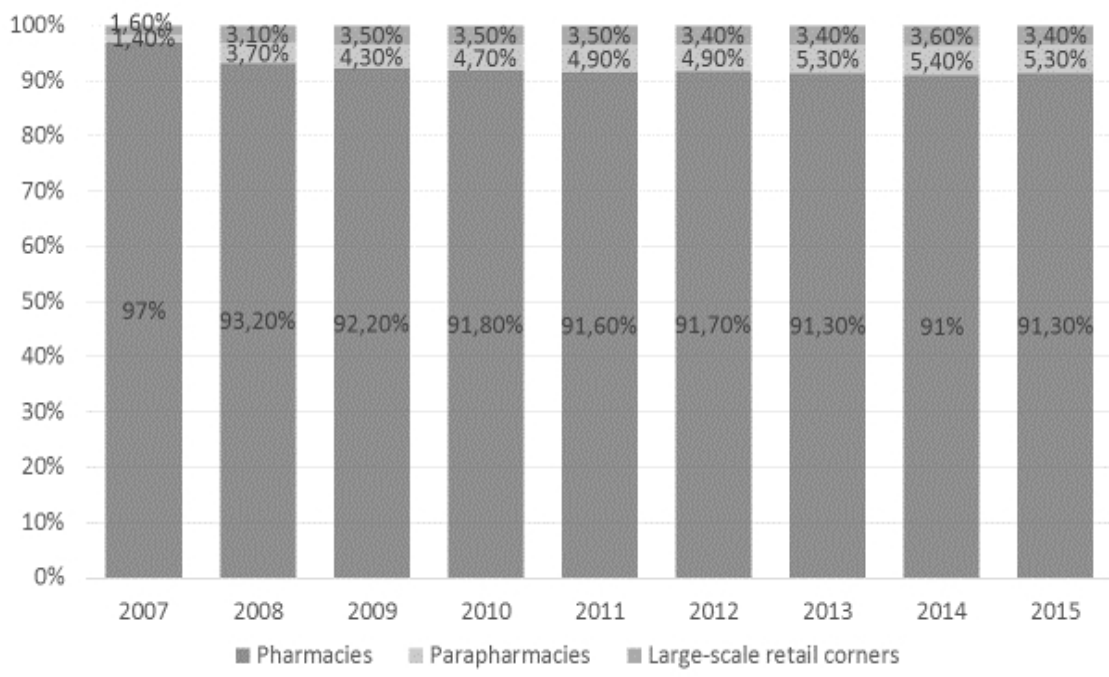

Source: Centro Studi Assosalute, 2016.

- Increase in the number of pharmacies, especially small-sized pharmacies, where it is possible to buy pharmaceuticals. Although the opening of new pharmacies still remains regulated by the Organization Chart (i.e. "Pianta Organica"), in compliance with the "Cresci Italia" Decree, there has been a consistent reduction in the number of residents required for the opening of new points of sale. The reform has also simplified procedures for the opening and assignment of pharmacies, as well as the management of inheritance, personnel hiring, shifts, opening hours and discounts. In the last decade, the amount of pharmacies which sell non-prescription drugs in the domestic territory has therefore increased considerably - from about 16,000 to 18,609 stores-(Centro Studi Assosalute, 2005, 2016), especially the number of small-sized pharmacies (i.e. pharmacies with a revenues of less than 327,000.00 € per year) (Centro Studi Assosalute, 2016). Furthermore, pharmacies have been steadily refining their marketing policies and services. In particular, local pharmacies are now offering healthcare services to citizens such as booking of specialist outpatient services, collection of medical reports, and so on.

Increase in the number of parapharmacies and corners in large-scale retail stores. In the last decade, following liberalization, the total number of parapharmacies and corners in large-scale retail stores selling nonprescription drugs has more than doubled. 
Figure 2. Number of parapharmacies and corners in large-scale retail stores 2007-2015

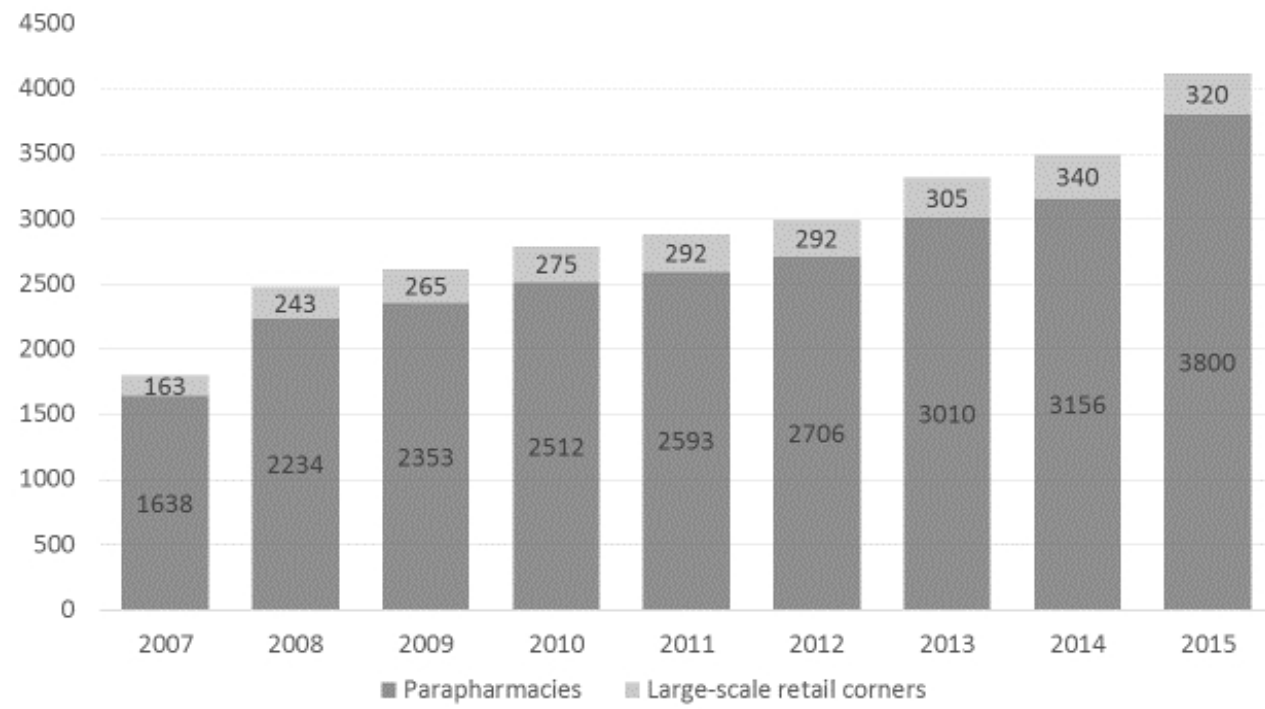

Source: Centro Studi Assosalute, 2016.

Although pharmacies still remain the main physical channel for medicinal product sale (e.g. ethical drugs, SOP, OTC), they are quickly losing market shares in favor of other channels, for which, however, drug sale is a small revenue source in comparison with that derived from the sale of other health-related products (e.g. parapharmaceutical, dietary, personal hygiene, beauty, hygiene, and notified products; herbal homeopathic remedies, nutritional supplements, and medical-surgical devices). For example, in corners of large-scale retail stores the share of non-prescription drugs and non-pharmaceutical products amount to 9.9 and $90.1 \%$ of total sale, respectively.

Pharmacies offer on average a wider assortment of SOP and OTC drugs compared to that offered by parapharmacies and corners of large-scale retail stores, whereas corners tend to mainly focus on high-turnover products. Moreover, with regard to the number of points of sale, corners in large-scale retail stores grow at a slower pace than parapharmacies, partially because such corners are usually opened in large format (e.g. superstores and hypermarkets). However, small-medium sized formats appear to be more successful in the Italian market (e.g. supermarkets). An example is represented by Coop, the first large-scale distribution company in Italy with a turnover of 12.42 billion euros, which operates on the domestic territory with 102 hypermarkets and 1,087 supermarkets. It entered the pharmaceutical market in 2006, and in July 2015 its corners amounted to a staggering total of 129, of which 101 were located in hypermarkets and 8 in supermarkets. Coop's corners offer an assortment of about 2,900 items, of 
which about 2,300 consists of parapharmaceuticals. Coop is also the only company to have developed and commercialized private label drugs (i.e. acetylsalicylic acid + ascorbic acid, paracetamol, calefred, carbocysteine syrup, acetylcysteine, and flurbiprofen mouthwash and spray) (Coop, 2014).

\section{Retailing mix in the pharmaceutical offering of large-scale retail companies $v s$. the pharmacy channel.}

Following a market-driven approach (Brondoni, 2008; Brondoni, 2009; Gnecchi, 2009; Brondoni and Musso, 2010; Brondoni et al., 2013), large-scale retail companies in the grocery sector have undergone a continuous process of development and growth highly influenced by market opportunities. One example is represented by the pharmaceutical market reform, which large-scale retailers, especially those with a high market share, have been able to promptly seize and exploit to their advantage. Indeed, towards the end of 2007, the year following the introduction of the "Bersani" Law, about 160 pharmaceutical corners were operating on the Italian market. Since then, their number has increased. This success is likely due to a much more efficient service offered by this sale channel compared to that offered by parapharmacies or pharmacies. This improved efficiency and efficacy can be probably ascribed to the expertise, abilities, relationships, technologies, and managerial skills that such enterprises have accrued over time. Moreover, supply organization, choices on assortment, decisions on private labels, pricing, and communication policies as well as merchandising activities are all heavily centralized, thus providing an advantage typical of economies of scale.

A thorough evaluation of the retailing mix levers (i.e. assortment, private label, merchandising, communication, and pricing) clearly points to the peculiarity of large-scale retail corners with respect to pharmacies, the main format of drug sale.

Generally, the assortment consists of the whole range of products made available to consumers at a certain place, time, and price. Assortment policy levers include breath, depth, and variety that can be assessed either at the distribution or category level. If the analysis is carried out at the distribution/point of sale level, the extent of assortment breadth is defined by the number of product categories offered by the store. A measure of variety, on the other hand, is given by the number of consumption segments offered for each category. Finally, the extent of depth is directly proportional to the number of brands offered for each consumption segment.

With regard to breadth and depth, it is possible to define four kinds of assortment based on their specialization degree (Baccarani, 2001). An allencompassing assortment is characterized by high levels of breadth and depth (i.e. stores make available a large number of varieties and sizable 
quantities of products able to meet different customer needs). The opposite situation, which takes place when both breadth and depth are considerably downsized, gives rise to the emergency assortment, which is developed to meet sudden customer needs. When we register low levels of depth and high levels of breadth, we can define the assortment as despecialized. Conversely, a specialized assortment is characterized by high depth and low breadth levels.

When we consider single pharmacies, we can observe that all these formats have developed a specialized assortment - all market offerings are aimed at treating and/or preventing diseases and developing wellness. In contrast, large-scale retailers can sell pharmaceutical products in either specialized stores outside large-scale groceries - in this case, they develop a specialized assortment format-or inside despecialized stores (e.g. superstores, hypermarkets, etc.). In this regard, despecialization is achieved by modifying both core and peripheral offerings: the core offering is enriched by the addition of new product categories (e.g. drugs and health products), whereas the peripheral offering is improved by the introduction of ancillary services related to the sale of drugs (i.e. pre-sale, sale, and postsale). Thus, in recent years, large-scale retailers have become increasingly despecialized due to the inclusion in their traditional offerings (e.g. food, household and pet products) of several new product categories such as drugs and health products.

With regard to assortment composition, it is important to point out that pharmacy assortments are generally made up of pharmaceutical specialties, extra-pharmaceuticals, or non-pharmaceuticals. Pharmaceutical specialties include special medicines (i.e. ethical drugs, SOP and OTC) or generics (i.e. semi branded, branded and unbranded). Ethical drugs can only be purchased with a prescription, while SOP and OTC do not require any prescription. Generics contain active ingredients equivalent to those of other drugs whose patent has already expired, and can be classified into prescription or non-prescription drugs. Extra-pharmaceuticals are a significant source of profit for pharmacies, because they include different product lines such as non-notified OTC, in vitro diagnostic chemical devices, medical devices (e.g. syringes, needles etc.), complementary medicine (e.g. herbal and homeopathic drugs), nutrition and hygiene baby care products, nutritional supplements for celiac disease or diabetes patients, cosmetics, hygiene products for the body and oral cavity, perfumery products, parapharmaceuticals (e.g. dressing or orthopedic products), and veterinary goods (Cuomo et al., 2010).

Large-scale retail corners, unlike pharmacies, cannot sell drugs that need medical prescription; their assortment is therefore mainly based on nonprescription drugs, extra-pharmaceuticals, and non-pharmaceuticals. 
Specifically, non-prescription drugs include the following:

OTC; i.e. drugs that can be promoted to the public and are easily accessible in the point of sale (i.e. self-service);

SOP; i.e. drugs that cannot be promoted to the public and are not easily accessible in the point of sale.

Non-pharmaceutical products can be generally classified into notified products (e.g. nutritional or dietary supplements, medical devices, herbal preparations, homeopathic drugs, and medical-surgical equipment), nutritional products, parapharmaceuticals (e.g. medical-surgical or diagnostic instruments, wound care products, eye care products, and products for children and the elderly) as well as unregistered hygiene and beauty products (Centro Studi Assosalute, 2015). Notably, notified products have a considerably lower importance here than in other channels. As a result, a major part of the assortment and sales is constituted by nutritional, hygiene, and beauty products, which represent about $43 \%$ of total sales of nonpharmaceutical products (Centro Studi Assosalute, 2016).

Corners can also sell non-prescription galenic compounds as well as veterinary drugs with prescription. In addition, all stores licensed to sell nonprescription drugs, including large-scale retail corners, can sell their products online in compliance with Italian regulations. Finally, although private label products can be part of the assortment, in the Italian market, only the leading brand Coop Italia has been able to develop several private label products, generating savings of up to 50\% on average (Coop, 2014; Coop 2015).

Merchandising policies coincide with assortment strategies, which mainly relate to store and merchandise layout and display space allocation. Such strategies are not only aimed at improving overall profit, but also at respecting competitive market relations, especially those among suppliers, notwithstanding the need to create added value for customers and increase profitability.

With regard to store layout, two joint models are usually chosen by large-scale retail corners: the grid model and the free flow/boutique model. While the former increases the display surface compared to the total available surface of a store, thus generating higher revenues, the latter simplifies the consumer purchase process, thereby meeting increasingly higher information needs.

Regarding merchandise layout, many retailers tend to group together similar categories of products and place side by side categories having similar use (e.g. products for cardiovascular disease), same customers (e.g. pregnant women), or same period of sale (e.g. suntan lotions).

As for space allocation given to product lines in large-scale retail stores, we can often notice dispersion in the case of goods with an high frequency of purchase, and, conversely, a more effective placement of those 
products with a greater unitary margin (i.e. margin placement). Since the choice of this space allocation might create confusion in the customer, many large scale retailers tend to develop their assortments according to visual merchandising principles based on "exhibit clarity". We can thus distinguish three main types of placements: 1) segment vertical display and brand horizontal display for product family; 2) segment vertical display and brand vertical display for product family; 3) brand vertical display and segment horizontal display for product family; 4) brand vertical display and segment vertical display for product family.

As far as merchandising is concerned, large-scale retail corners appear to give greater importance to merchandising (e.g. store and merchandise layout and display space allocation) with respect to pharmacies, especially small or medium-sized stores, where the display of products is frequently organized in a different way than what described above. Indeed, large-scale retail distributors apply the same management principles for drug display as those adopted for other products, according to corporate store brand policies, with the final goal of improving store sales performance through optimization of intra- and inter-product display opportunities across the entire point of sale. Pharmaceutical display therefore depends on general merchandising policies implemented by the point of sale aimed at the following goals: 1) increasing sales volume of highly marginal products; 2) "leveling" demand spikes; 3) optimizing profits of family, line, or single products; 4) building and strengthening the store brand image; 5) minimizing surplus and inventories; 6) maximizing product display opportunities (Riboldazzi, 2007).

Finally, in both pharmacies and large-scale retail corners there can be often found a customer care/waiting area placed between a self-service area and the behind-the-counter area, which is intended for the exclusive use of the pharmacist, and where all drugs that cannot be directly purchased by customers are stored. In corners, behind-the-counter drugs are for the major part non-prescription SOPs, whereas in pharmacies these drugs include nonprescription SOPs together with ethical drugs and generics requiring medical prescription.

Focusing on communication policies, it can be argued that pharmaceutical retailers often combine marketing communication with institutional and organizational communication. In this context, communication mainly pertains to products, brands, and companies. Common types of marketing communication include in-store communication (e.g. in-store signage), promotions (e.g. discounts, vouchers, etc.), direct marketing (e.g. loyalty cards and sms) and media advertising (i.e. advertisement published on journals or specialized magazines). In particular, with regard to drug assortment communication, companies are supposed to 
comply with Italian Law regulations, such as Leg. Decree No. 219/2016, which establishes that only OTC can be subject to marketing communication. The decree and its subsequent amendments also determines both minimum and banned content, which, before being disseminated, must be in any case approved by a regulatory body appointed by the Ministry of Health - the authorization has a two-year expiration date. Regarding health products, such as nutritional supplements or herbal drugs, except for medical devices, no prior authorization is required. These products are therefore less subject to strict legislative restrictions compared to other drugs, even though non-pharmaceutical product advertisement should not refer by any means to the possibility of preventing, treating, and healing any forms of human disease.

In addition, on February $17^{\text {th }}, 2010$ the Ministry of Health provided a series of guidelines for regulating online advertising, toll-free numbers, SMS and MMS (Centro Studi Assosalute, 2016). Contrary to pharmacies, largescale retail corners can also benefit from all combined communication policies developed by the point of sale and the distribution chain. Furthermore, pharmaceutical offerings often mirror the overall mission of the large-scale retailer.

About communication tools, many corners often resort to traditional in-store communication or communication through new technologies (e.g. general, departmental or linear signage, in-store leaflets, in-store radio, selfscanning, e-labels, in-store videos, etc.). Moreover, large-scale retailers often use promotions and cross promotions such as discount vouchers for future purchases of drug after a minimum amount purchase.

Finally, considering the price lever, we can notice that the pricing system of non-prescription drugs has been liberalized; hence prices can be fixed by each single point of sale, provided that the highest ex-factory price and any upward changes are promptly communicated to AIFA. Moreover, it is no longer mandatory to display the drug price on a label (Centro Studi Assosalute, 2015).

Overall, drug pricing appears to be influenced by a number of internal variables (e.g. expenditures for store, warehouse, and management) and external variables (e.g. environment and competition) as well as factors linked to business goals (e.g. market shares, competitive positioning, etc.).

Following the drug retail distribution reform, price competition for OTC, SOP, parapharmaceuticals and extra-pharmaceuticals has dramatically increased and therefore price variations have become more and more frequent. In corners, such price variations take place at a much faster pace than other formats probably because large-scale retailers need to quickly react to changes in competitors' pricing strategies while keeping into account the short-term goals of the product category, brand promotional policies, 
relationships with suppliers and, lastly, the added value provided to the customer with respect to such competitors.

\section{Conclusion}

In the last few years, the Italian large-scale drug retail system has undergone a series of regulatory actions that have modified its structure, competitiveness, and operations. In particular, 1) the sale of non-prescription drugs has been legalized not only in pharmacies, but in other stores as well, such as parapharmacies and points of sale managed by large-scale retailers; 2) the quantity of pharmacies has dramatically increased; 3) the role of parapharmacies and above all large-scale retailers in the sale of nonprescription drugs and extra-pharmaceutical products has become prominent.

The reason large-scale retailer have been so successful in drug sales can be traced to the skills, expertise, state-of-the art technologies, networks, and economies of scale that such retailers have been able to develop over time, while striving to achieve efficient and profitable services. Indeed, in large-scale retail corners, pharmaceutical retailing mix levers are managed dynamically and in a competitive perspective. Hence, large-scale retailers, thanks to dynamic product assortment aggregation, visual merchandising optimization, competitive pricing, and efficient communication management have been able to quickly develop and launch on the market value-added pharmaceutical offerings and, consequently, achieve drug category objectives according to overall store brand orientations.

Moreover, the choice of large-scale retail distributors to sell drugs has spread innovation, thereby improving customer loyalty. When drugs are sold in dedicated stores, innovation refers to point of sale portfolio (e.g. superstores, hypermarkets, supermarkets, etc.), which thus gains a new specialized format, the pharmacy. When drugs are sold in already existing formats (e.g. areas inside supermarkets), innovation comes from the commercial offering itself, which increases its breadth through the addition of pharmaceuticals and ancillary services to its assortment.

Specifically, the pharmaceutical offering by large-scale retailers generates innovation in:

1) business functions developed by such retailers, which now includes other complementary functions (e.g. supply, transport, storage, etc) aimed at supporting the management of new pharmaceutical product categories;

2) market offering meant as the combination of those different attributes (e.g. pre-selection, service speed, comfort and pre-sale, sale and post-sale services) that form the entire format. The core offering is improved thanks to the introduction of new pharmaceutical product categories, whereas 
the peripheral offering is enhanced by the development of pre-sale, sale and post-sale services related to the sale of such categories.

3) retailing mix, especially with regard to assortment policy management, private labels, pricing, communication, and visual merchandising, which all vary because of the management of the pharmaceutical product category, which ultimately relies on the team effort among the categories offered in the store.

\section{References:}

1. Alexander, A., Pollard J. (2000). Banks, Grocers and the Changing Retailing of Financial Services in Britain. Journal of Retailing and Consumer Services, 7, 3, 137-147. https://doi.org/10.1016/S09696989(99)00020-X

2. Baccarani, C. (Ed.) (2001). Imprese commerciali e sistema distributivo. Una visione economico-manageriale. Turin: Giappichelli.

3. Basker, E., Klimek, S. and Hoang Van, P. (2012). Supersize It: The Growth of Retail Chains and the Rise of the "Big-Box" Store. Journal of Economics \& Management Strategy, 21,3, 541-582. doi:10.1111/j.1530-9134.2012.00339.x

4. Brondoni, S.M. (2008). Market-Driven Management, Competitive Space and Global Network. Symphonya. Emerging Issues in Management (www.unimib.it/symphonya), 1, 14-27. http://dx.doi.org/10.4468/2008.1.02brondoni.

5. Brondoni, S.M. (2009). Market-Driven Management, Competitive Customer Value and Global Networks. Symphonya. Emerging Issues in Management (symphonya.unimib.it), 1, 8-25. http://dx.doi.org/10.4468/2009.1.02brondoni

6. Brondoni, S.M., Corniani, M., \& Riboldazzi, S. (2013). Global Retailers, Market-Driven Management and Innovation. International Journal of Economic Behavior, 3, 27-40.

7. Brondoni, S.M., Musso, F. (2010). Ouverture de 'Marketing Channels and Global Markets'. Symphonya. Emerging Issues in Management (symphonya.unimib.it), 1, 1-6, 2010. http://dx.doi.org/10.4468/2010.1.01ouverture

8. Burt, S. (1991). Trends in the Internationalization of Grocery Retailing: the European Experience. The International Review of Retail, Distribution and Consumer Research, 1, 4, 487-515. http://dx.doi.org/10.1080/09593969100000005

9. Centro Studi Assosalute. (2005, 2015, 2016). Numeri e indici dell'automedicazione. 
http://assosalute.federchimica.it/Libraries/Numeri_e_Indici__ASSOSALUTE/Assosalute2016_WEB_corretto.sflb.ashx

10. Coop. (2014). Undicesimo Rapporto Sociale Nazionale delle Cooperative di Consumatori. Retrieved from http://www.ecoop.it/CoopRepository/COOP/CoopItalia/coop-rs-

2015/Undicesimo_Rapporto_Sociale_Nazionale_Della_Cooperazion e_Di_Consumatori.pdf

11. Coop. (2015). Dodicesimo Rapporto Sociale Nazionale delle Cooperative di Consumatori. Retrieved from http://www.ecoop.it/CoopRepository/COOP/CoopItalia/coop-rs2016/Sfogliatore_RS_Coop2016_Integrale/RS2015.pdf

12. Cuomo, M.T., Testa, M., Tortora, D. (2010). La gestione della farmacia. Guida pratica al miglioramento delle performance. Turin: Giappichelli.

13. Efpia. (2016). The Pharmaceutical Industry in Figures. Retrieved from https://www.efpia.eu/media/25055/the-pharmaceutical-industryin-figures-june-2016.pdf

14. Federfarma. (2015). La farmacia italiana. Retrieved from https://www.federfarma.it/Documenti/farmacia_italiana2015.aspx

15. Gnecchi, F. (2009). Market-Driven Management, Market Space and Value Proposition. Symphonya. Emerging Issues in Management (symphonya.unimib.it), 2 , 33-45. http://dx.doi.org/10.4468/2009.2.04gnecchi

16. Martinelli, E. (2012). Distributori Grocery in Convergenza. Esperienze a Confronto. Milan: Franco Angeli.

17. Musso, F. (2010). Innovation in Marketing Channels. Symphonya. Emerging Issues in Management (www.unimib.it/symphonya), 1, 2342. http://dx.doi.org/10.4468/2010.1.04musso

18. Riboldazzi, S. (2007). Competitive Customer Value nelle imprese della grande distribuzione. Torino: Giappichelli.

19. Riboldazzi, S. (2010). Retail Policies in the Global Gasoline Market. Symphonya. Emerging Issues in Management (symphonya.unimib.it), 1, 2010, pp. 86-101 http://dx.doi.org/10.4468/2010.1.09riboldazzi

20. Riboldazzi, S., (2012). Market-Driven Management, Global Market and Prescribers, in S.M. Brondoni (ed.), Managerial Economics and Global Corporations (pp. 111-124), Torino, Giappichelli.

21. Riboldazzi, S. (2015a). Global Markets and Development Policies in Large-Scale Retailers. Symphonya. Emerging Issues in Management (symphonya.unimib.it), 5 , 8-28. http://dx.doi.org/10.4468/2015.5.02riboldazzi

22. Riboldazzi, S. (2015b) R\&D and Product Engeneering in Global Pharmaceutical Companies. Symphonya. Emerging Issues in 
Management (symphonya.unimib.it), 2, pp. $57 \quad-74$. http://dx.doi.org/10.4468/2015.2.05riboldazzi

23. Risso, M. (2010). Large Retailers' Financial Services. Symphonya. Emerging Issues in Management (symphonya.unimib.it), 1, 2010, pp. 65-75 http://dx.doi.org/10.4468/2010.1.07risso

24. Robinson, T. M., Clarke-Hill, C. M. (1990). Directional Growth by European Retailers. International Journal of Retail \& Distribution Management, 18, 5. 